\title{
PELATIHAN PEMBUATAN SILASE GAMAL (Gliricida sepium) DALAM MENGATASI KEKURANGAN PAKAN DI DESA KUAKEN KECAMATAN NOEMUTI TIMUR KABUPATEN TTU
}

\author{
Paulus Klau Tahuk ${ }^{1}$ dan Gerson Frans Bira ${ }^{2}$ \\ ${ }^{1,2)}$ Program Studi Peternakan, Fakultas Pertanian, Universitas Timor, Indonesia \\ email: Paulklau@yahoo.co.id ${ }^{1)}$; Gersonbira@yahoo.co.id ${ }^{2)}$
}

\begin{tabular}{|l|l|l|}
\hline Dikirim: 11-11-2020 & Direvisi: 29-11-2021 & Diterbitkan: 28-02-2021
\end{tabular}

\begin{abstract}
Abstrak
Tujuan dari kegiatan pengabdian pada masyarakat ini adalah membantu kelompok tani dalam menyediakan pakan ternak ruminansia pada musim kemarau melalui teknologi pembuatan silase. Kegiatan dilaksanakan di Kelompok Wanita Tani (KWT) Desa Kuaken Kecamatan Noemuti Timur Kabupaten TTU selama 3 bulan. Alat dan bahan yang digunakan adalah kuesioner, drum plastik (kapasitas $150 \mathrm{~kg}$ ), alat potong (parang), terpal, kamera dan alat tulis, hijauan gamal, lamtoro, dedak padi dan gula pasir. Metode yang digunakan adalah workshop. Serta pengisisan kuisioner yang berisi pertanyaan untuk dijawab sebelum dan sesudah diberikan ceramah. Hasil pengabdian menunjukkan bahwa antusiasme masyarakat cukup tinggi dan memberikan respon yang positif terhadap praktek pembuatan silase, dengan dengan tingkat pemahaman mencapai $82,5 \%$. Secara fisik, silase yang dihasilkan memenuhi kriteria silase yang baik yakni memiliki bau khas silase (asam), warna hijau kecokelatan dan bertekstur padat, $\mathrm{pH}$ 3,48 dengan tidak adanya jamur. Kandungan nutrisi silase yang tergolong tinggi dengan kandungan PK 10,83\% dan EM mencapai 3244,56 Kkal $/ \mathrm{kg}$. BK; serta palatabilitas ternak terhadap silase yang tergolong tinggi. Disimpulkan bahwa kegiatan pelatihan pembuatan pakan ternak berbahan dasar gamal dengan pendekatan teknologi pembuatan silase dalam mengatasi kekurangan pakan di Desa Kuaken Kecamatan Noemuti Timur Kabupaten TTU, telah dilaksanakan dengan baik dan berkontribusi dalam meningkatkan pengetahuan petani/peternak.
\end{abstract}

Kata Kunci: Silase gamal, kualitas silase, Desa Kuaken, palatabilitas, tingkat pengetahuan

\begin{abstract}
The purpose of this community service activity is to assist farmer groups in providing ruminant feed during the dry season through silage-making technology. The activity was carried out in the Women Farmers Group (WFG) in Kuaken Village, East Noemuti District, TTU Regency for 3 months. The tools and materials used were questionnaires, plastic drums (150 kg capacity), cutting tools (machetes), tarpaulins, cameras and stationery, forage gamal, lamtoro, rice bran and sugar. The method used is a workshop. As well as filling out a questionnaire containing questions to be answered before and after the lecture. The results of the community service show that the enthusiasm of the community is quite high and gives a positive response to the practice of making silage, with a level of understanding reaching $82.5 \%$. Physically, the resulting silage meets the criteria for good silage, which has a distinctive smell of silage (sour), brownish green color and solid texture, $\mathrm{pH} 3.48$ in the absence of mold. The high nutritional content of silage with CP content of $10.83 \%$ and EM reached $3244.56 \mathrm{Kcal} / \mathrm{kg}$. CP; and the relatively high palatability of livestock against silage. It was concluded that the training activities for making animal feed made from gamal with a silage-making technology approach in overcoming feed shortages in Kuaken Village, East Noemuti District, TTU Regency, had been carried out well and contributed to increasing farmers/breeders' knowledge.
\end{abstract}

Keywords: Gamal silage, silage quality, Kuaken Village, palatability, level of knowledge 


\section{PENDAHULUAN}

Salah satu ciri dari peternakan lahan kering adalah musim hujan yang pendek (2-3 bulan) dan musim kemarau yang panjang (8-9 bulan). Dengan ciri tersebut maka ketersediaan pakanpun akan sangat berfluktuatif mengikuti musim sehingga berdampak pada produktivitas ternak yang berfluktuatif pula. Diperlukan sentuhan teknologi sederhana untuk menjamin ketersediaan pakan sepanjang musim. Silase adalah teknik pengawetan pakan melalui proses fermentasi karbohidrat terlarut membentuk asam laktat dalam silo oleh bakteri asam laktat (McDonald et al., 2002), dan menambah masa simpan hijauan sehingga dapat dimanfaatkan dalam waktu yang lama terutama pada saat musim kemarau (Wati et al., 2018). Dalam pembuatan silase, hal penting yangperlu diperhatikan adalah bahan yang digunakan. Dimana selain memilih hijauan yang disukai ternak, juga perlu diperhatikan jenis bahan pakan karena turut mempengaruhi karakteristik silase yang dihasilkan (Tahuk et al., 2020).

Gamal (Gliricidia sepium) merupakan salah satu leguminosa pohon yang disukai ternak karenakandungan nutrisi terutama protein yang cukup tinggi. Namun demikian, gamal memiliki zat antinutrisi (Sikone dan Bira, 2016). Oleh karena itu sebelum diberikan ke ternak, hijauan gamal perlu diangin-anginkan terlebih dahulu untuk mengurangi bau khas coumarin yang merupakan salah satu factor penyebab rendahnya tingkat palatabilitas daun gamal.

Hijauan gamal berpotensi besar untuk diawetkan dan dimanfaatkan sebagai pakan ternak pada saat paceklik. Selain karena produksi biomasa yang tinggi pada musim hujan juga, karena ketersediaan nutrisi yang dimiliki terutama kandungan PK $(21,377$ \%BK) yang cukup tinggi dapat memenuhi kebutuhan ternak ruminansia. Tanaman gamal juga sangat potensial dikembangkan sebagai makanan ternak karena memiliki kelebihan seperti dapat tumbuh dengan cepat di daerah kering (Mayasari et al., 2012). Sesuai kondisi biofisik alami Nusa Tenggara Timur yang kering dan lahan kritis, tanaman gamal merupakan tanaman pilihan yang dapat dikembangkan.

Desa Kuaken, Kecamatan Noemuti, Timor Tengah Utara merupakan salah satu wilayah potensial untuk pengembangan ternak potong ruminansia, terutama sapi bali. Daerah ini sebagian besar mata pencaharian masyarakat adalah bertani dan beternak. Meskipun cukup potensial sebagai wilayah pengembangan ternak potong, kondisi peternakan di Desa Kuaken umumnya sama seperti daerah-daerah iklim tropis lainnya yakni terjadinya kekurangan pakan pada musim kemarau. Akibatnya produktivitas ternak yang dipelihara petani/peternak tidak optimal sepanjang tahun. Melihat kondisi ini, upaya untuk mempertahankan produktivitas ternak sepanjang tahun perlu dilakukan guna mendukung perekonomian masyarakat. Oleh karena itu, pendampingan dan pelatihan masyarakat Desa Kuaken dengan teknologi pengawetan pakan terutama pembuatan silase merupakan hal positif untuk pengembangan ternak potong di daerahtersebut.

\section{METODE}

\section{Tempat dan Waktu Pengabdian}

Kegiatan pengabdian ini dilaksanakan di Kelompok Wanita Tani, Desa Kuaken Kecamatan Noemuti Timur Kabupaten Timor Tengah Utara (TTU), propinsi Nusa Tenggara 
Timur (NTT). Pengabdian dilaksanakan pada bulan Agustus-Oktober 2020, termasuk persiapan dan pelaporan.

\section{Alat dan bahan}

Peralatan yang digunakan adalah kuisioner, drum plastik (kapasitas $150 \mathrm{~kg}$ ), alat potong (parang), terpal, timbangan gantung, kamera dan alat tulis. Bahan terdiri dari hijauan gamal, lamtoro, dedak padi dan gula pasir.

\section{Metode Pelaksanaan}

Metode yang digunakan dalam kegiatan pengabdian ini adalah ceramah dan praktek secara langsung (workshop) bersama kelompok tani. Untuk mengetahui tingkat pemahaman masyarakat tentang teknologi pembutan silase berbasis hijuan gamal, maka peternak diberikan kuisioner yang berisi pertanyaan untuk dijawab sebelum dan sesudah diberikan ceramah. Kemudian masyarakat diarahkan untuk membuat silase sendiri dengan pendampingan oleh tim pengabdian. 21 hari kemudian silase dibuka dan diuji kualitas fisik bersama masyarakat dan serta kimianya (sementara proses analisis) dan dilakukan uji palatabilitas pada ternak milik masyarakat.

Adapun tahapan-tahapan yang dilalui dalam proses pembuatan silase berbasis gamal digambarkan dalam bentuk skema :

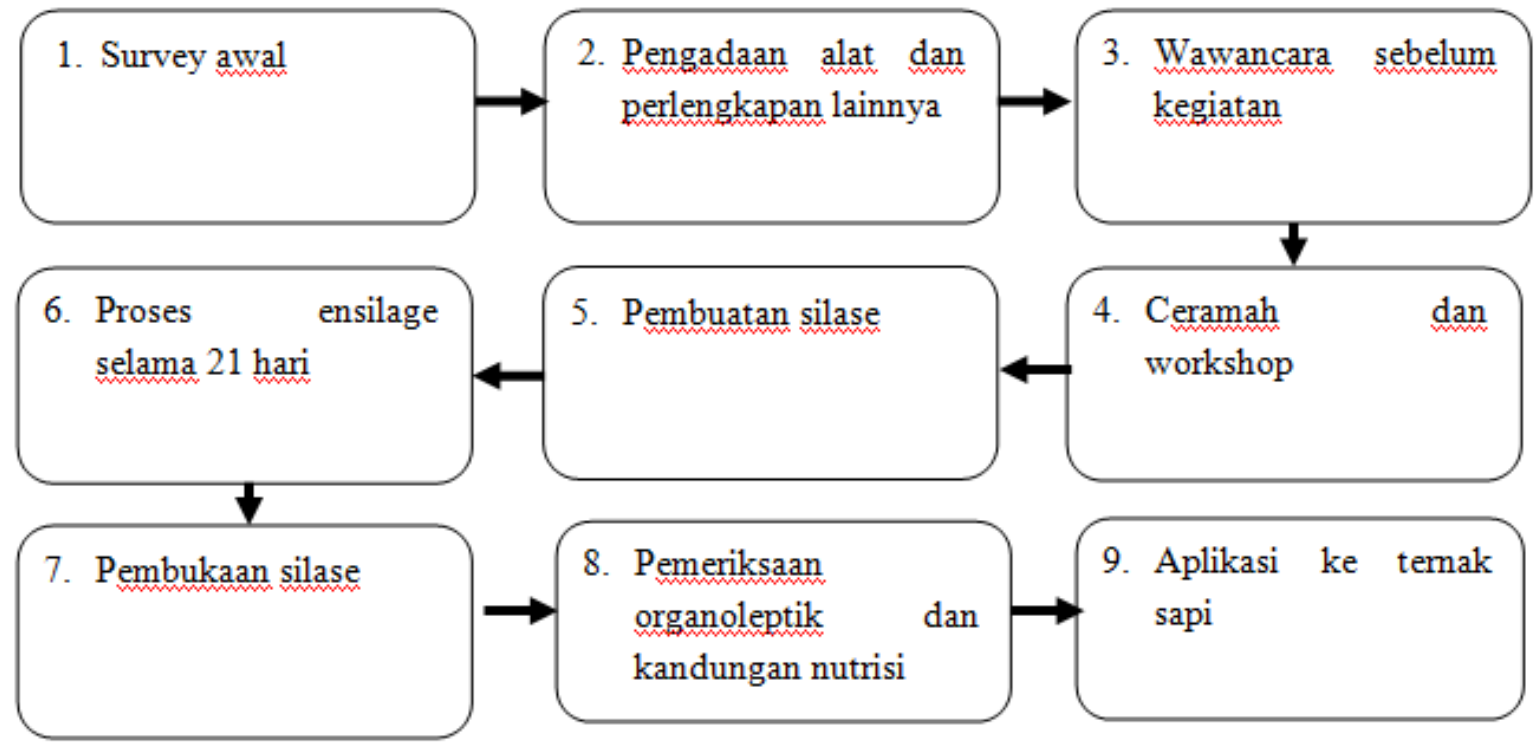

Gambar 1. Alur pelaksanaan kegiatan

\section{HASIL DAN PEMBAHASAN}

\section{Prosedur Pembuatan Silase Berbasis Gamal}

Adapun prosedur pembuatan silase berbasis hijauan gamal adalah : daun gamal dipotong dan diangin-anginkan selama 3 jam untuk menurunkan kadar air (60-70\%), kemudian dicacah dengan ukuran 3-5 cm. Cacahan tersebut ditimbang sebanyak $70 \%$ dengan aditif berupa dedak padi sebanyak $25 \%$ dan gula $5 \%$. Setelah itu dicampur dan diaduk hingga merata dan dimasukkan ke dalam silo sedikit demi sedikit sambil ditekan agar O2 (oksigen) dapat dileuarkan sebanyak mungkin sesuai prinsip fermentasi. Setelah terisi penuh, 
silo ditutup dan disimpan selama 21 hari dalam ruangan dengan suhu kamar agar terhindar dari paparan cahaya matahari secara langsung sehingga proses ensilage dapat berjalan sempurna

Setelah 21 hari, silo dibuka dan dilakukan penilaian terhadap kualitas silase komplit secara fisik dan kimia. Secara fisik, parameter yang diamati dan diukur adalah warna, aroma, tekstur, $\mathrm{pH}$ dan keberadaan jamur. Penilaian warna, tekstur, dan aroma dilakukan oleh panelis yang terdiri dari tim pengabdian dan anggota kelompok serta mahasiswa yang ikut terlibat. Penilaian secara organoleptik ini berdasarkan Tahuk et al. (2020), yakni dengan memberikan penilaian (skor) yang berkisar 1-3 (Tabel 1) yang merupakan gambaran kualitas silase yang dihasilkan.

Pengukuran $\mathrm{pH}$ silase komplit menggunakan $\mathrm{pH}$ digital. Langkah awal pengukuran adalah pH meter dikalibrasi menggunakan larutan buffer yang memiliki pH 2 dan 6 . Selanjutnya $\mathrm{pH}$ meter yang dikalibrasi dimasukkan ke dalam silo yang berisi silase dengan posisi elektroda $\mathrm{pH}$ menembus padatan silase dalam silo. Angka yang tertera pada $\mathrm{pH}$ meter merupakan nilai $\mathrm{pH}$ dari silase.

\section{Kualitas Fisik Silase Berbasis Gamal}

Silase yang baik dapat diketahui secara organoleptik seperti tekstur, warna, aroma, keberadaan jamur dan derajat keasaman (Tahuk et al., 2020). Dari Tabel 1 terlihat bahwa karakteristik fisik dari silase berbasis gamal yang diberi skor 1-3 tergolong tinggi. warna silase hijau kecokelatan dengan skor 3, bertekstur padat dengan skor 3, beraroma asam dengan skor 3 dan pH 3,48 atau dikategorikan baik sekali. Hal ini menunjukkan bahwa proses pembuatan serta ensilage berjalan dengan normal.

Tabel 1. Skoring penilian organoleptik

\begin{tabular}{lccc}
\hline Kualitas fisik & \multicolumn{3}{c}{ Skoring } \\
\cline { 2 - 4 } (organoleptik) & 3 & 2 & 1 \\
\hline Warna & $\begin{array}{c}\text { Hijau alami atau } \\
\text { hijau kekuningan }\end{array}$ & $\begin{array}{c}\text { Hijau gelap atau } \\
\text { kuning kecoklatan } \\
\text { Aroma }\end{array}$ & $\begin{array}{c}\text { Tidak asam atau } \\
\text { tidak busuk }\end{array}$ \\
Tekstur & Padat & Agak lembek & Busuk \\
pH & 3,0-4,2 Baik sekali & $4,2-4,5$ Baik & Lembek \\
Keberadaan jamur & Tidak ada & Cukup & $4,5-4,8$ Sedang \\
\hline
\end{tabular}

Menurut Hermanto (2011), warna silase yang baik adalah cokelat terang (kekuningan) dengan bau asam. Dilanjutkan oleh Siregar (1996), bahwa silase secara umum dikategorikan baik apabila mempunyai tekstur yang masih jelas seperti alaminya. Soekanto et al. (1980) menyatakan bahwa karakteristik aroma silase yang baik jika diberi rangking/skor 1-3 adalah yang ditunjukkan dengan skor 2 sampai 3 yaitu tidak asam atau tidak busuk sampai dengan bau asam, $\mathrm{pH}$ yang dihasilkan berkisar antara 3,75-4,55, dimana pada $\mathrm{pH}$ ini masih dalam kisaran dan kriteria yang ideal pada silase. Hermanto (2011) menyatakan, pH silase yang ideal berkisar 4,3-45 dan sangat ideal pada $\mathrm{pH} 3,8-4,2$. Hal-hal yang telah disebutkan 
memberi gambaran bahwa silase yang dibuat bersama masyarakat Desa Kuaken dikategorikan berkualitas secara fisik (organoleptik).

Tabel 2. Hasil Pengamatan Kualitas Fisik Silase Berbasis Gamal

\begin{tabular}{ll}
\hline Pengamatan & Nilai dan Skor \\
\hline Warna & Hijau kecokelatan/3 \\
Tekstur & Padat $/ 3$ \\
Aroma & Asam $/ 3$ \\
pH & $3,48 /$ baik sekali \\
Jamur & Tidak ada \\
\hline
\end{tabular}
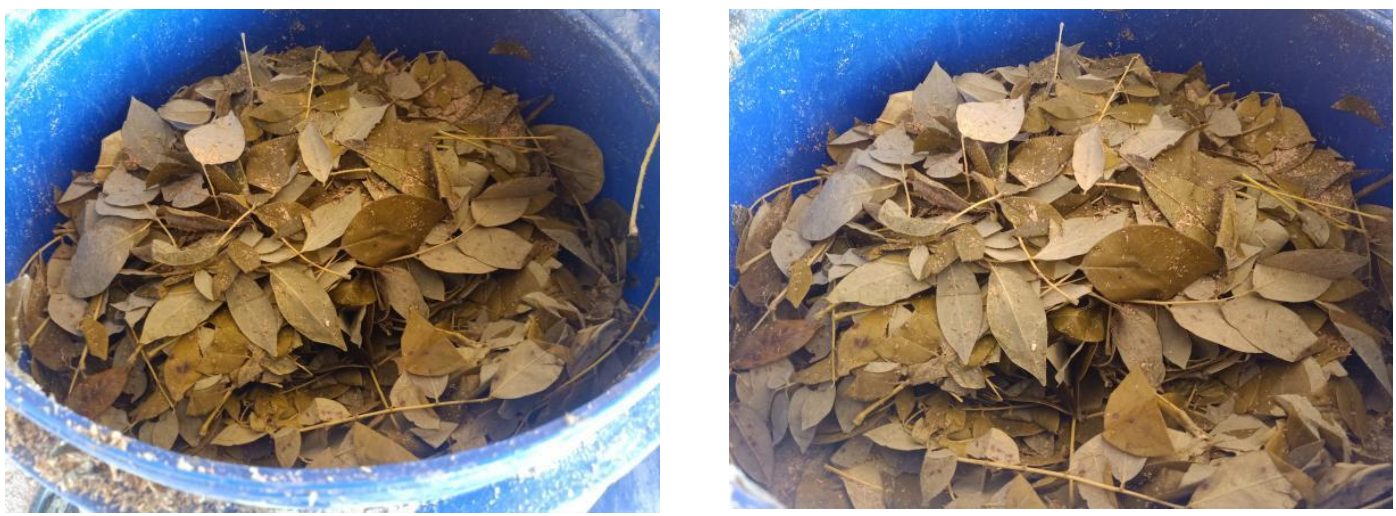

Gambar 2. Kualitas fisik silase berbasis gamal

\section{Kulitas kimia Silase Berbasis Gamal}

Kualitas suatu pakan dapat ditentukan melalui pendekatan analisis proksimat di laboratorium dengan mengukur komposisi kimia dari pakan tersebut. Komposisi kimia yang menentukan kualitas pakan meliputi protein kasarnya (PK), bahan kering (BK)/organik (BO) dan kandungan serat kasar (SK), lemak kasar (LK), bahan ekstrak tanpa nitrogen (BETN), karbohidrat $(\mathrm{CHO})$ dan energi metabolis (EM). Hasil uji proksimat terhadap silase berbasis gamal tertera pada Tabel 3 .

Tabel 3. Hasil analisis proksimat silase berbasis gamal

\begin{tabular}{|c|c|c|c|c|c|}
\hline \multirow{2}{*}{ Kandungan Nutrisi } & \multicolumn{4}{|c|}{ Silase Berbasis Gamal } & \multirow{2}{*}{ Rataan } \\
\hline & 1 & 2 & 3 & 4 & \\
\hline $\mathrm{BK}(\%)$ & 92,91 & 92,91 & 92,35 & 92,24 & 92,60 \\
\hline $\mathrm{BO}(\% \mathrm{BK})$ & 83,55 & 84,99 & 82,63 & 80,64 & 82,95 \\
\hline $\mathrm{PK}(\% \mathrm{BK})$ & 10,37 & 11,23 & 10,98 & 10,77 & 10,83 \\
\hline LK (\%BK) & 5,35 & 5,65 & 6,79 & 5,34 & 5,78 \\
\hline SK $(\% \mathrm{BK})$ & 12,47 & 12,11 & 13,84 & 13,88 & 13,07 \\
\hline $\mathrm{CHO}^{* *}(\% \mathrm{BK})$ & 61,31 & 62,60 & 58,73 & 60,53 & 60,79 \\
\hline BETN** (\%BK) & 48,84 & 50,50 & 44,89 & 45,25 & 47,37 \\
\hline $\mathrm{EM} * *(\mathrm{Kkal} / \mathrm{kg} \mathrm{BK})$ & $3.193,59$ & $3.282,61$ & $3.159,68$ & $3.342,35$ & 3244,56 \\
\hline
\end{tabular}

Keterangan : Hasil analisis laboratorium kimia pakan Fakultas Peternakan Universitas Nusa Cendana (2020). 
Hal ini berkaitan dengan bahan dasar yang digunakan dalam pembuatan silase. Walaupun adanya penambahan mikroba starter namun kadar protein masih rendah karena kandungan PK pada bijianjagung yang rendah. Sedangkan kandungan PK gamal jauh lebih tinggi. Kandungan nutrisi silase berbasis gamal dalam kegiatan pengabdian ini lebih tinggi dari laporan Tahuk dan Bira (2019), bahwa silase komplit dengan bahan gamal dan lamtoro memiliki kandungan nutrisi khususnya PK sebesar 10,48\%. Hal ini berkaitan dengan bahan dasar pembuatan silase yang sama.

\section{Palatabilitas silase}

Palatabilitas adalah derajat kesukaan pada makanan tertentu yang terpilih dan dimakan dengan adanya respon yang diberikan oleh ternak baik ruminansia maupun mamalia (Church dan Pond, 1988). Pada pengabdian ini, setelah 21 hari silase dipanen dan diangin-anginkan, selanjutnya diberikan ke ternak milik masyarakat Kelompok Wanita Tani Desa Kuaken. Sesuai pengamatan,nilai kesukaanternak sapi terhadap silase berbasis hijauan gamal yang dihasilkan tergolong tinggi dimana ketika diberikan ternak langsung mengkonsumsinya tanpa adaptasi walaupun ternak baru pertama kali diberikan silase tersebut
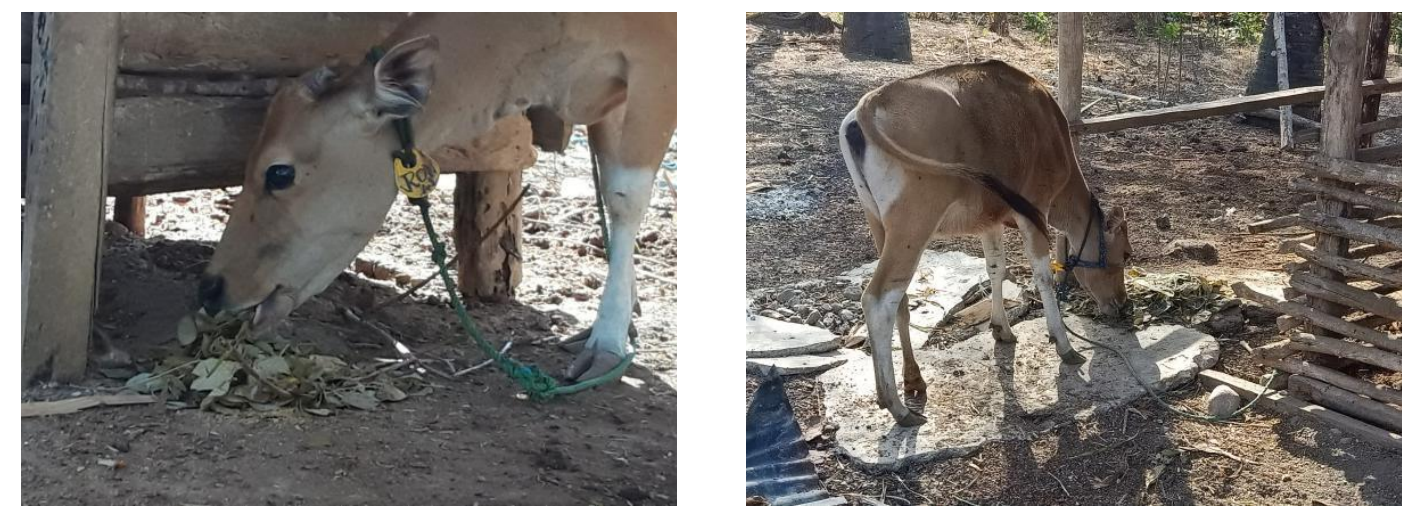

Gambar 3. Palatabilitas ternak sapi terhadap silase berbasis gamal

\section{Peningkatan pengetahuan}

Tingkat pemahaman dan pengetahuan masyarakat Desa Kuaken yang lebih difokuskan pada KWT Mawar dapat dilihat dari kuesioner yang diberikan sebelum dan sesudah kegiatan. Antusias anggota kelompok tergolong tinggi dalam kegiatan ini yang dapat dilihat dari tingkat kehadirannya (partisipasi). Dimana dari total 20 anggota kelompok, yang hadir dalam kegiatan berjumlah 15 orang atau mencapai75\%.

KWT Mawar umumnya memiliki berbagai kegiatan yang dilakukan dan diantaranya adalah beternak. Ternak yang diperoleh merupakan ternak sapi bantuan pemerintah dengan sistem perguliran. Dilihat dari tingkat pendidikan, maka anggota kelompok yang berpendidikan SMA hanya 5\% (1 orang), SMP 25\% (5 orang), SD 50\% (10 orang) dan tidak bersekolah $20 \%$ (4 0rang) dan 100\% anggota bekerja sebagai petani/peternak. Kondisi ini membuktikan bahwa tingkat pendidikan anggota kelompok sangat rendah sehingga daya terima (adopsi) terhadap ilmu pengetahuan dan teknologi yang baru perlu dilakukan secara bertahap dan terus menerus. 
Penilaian awal (pre test) terhadap kemampuan anggota KWT Mawar menunjukkan bahwa rata-rata tingkat pemahaman terhadap silase hanya $35 \%$ dan hal ini menunjukkan bahwa anggota kelompok masih memiliki pemahaman rendah sampai sedang tentang pembuatan silase. Selanjutnya setelah dilakukannya pelatihan dan praktek secara langsung pembuatan silase, tingkat pemahaman anggota kelompok tentang teknologipembuatan silase komplit meningkat dengan nilai rata-rata $82,5 \%$. Proses pengisian kuesioner dibantu oleh mahasiswa yang ikut terlibat. Hal ini menggambarkan bahwa kegiatan pelatihan pembuatan silase komplit dalam program pengabdian ini berkontribusi positif dalam meningkatkan pengetahuan peternak.

\section{SIMPULAN}

Kegiatan Pelatihan pembuatan pakan ternak berbahan dasar hijauan gamal dengan pendekatan teknologi silase dalam mengatasi kekurangan pakan di Desa Kuaken Kecamatan Noemuti Timur Kabupaten TTU, telah dilaksanakan dengan baik. Antusiasme dan respon yang positif ditunjukkan oleh partisipiasi masyarakat yang sangat tinggi. Partispasi peternak dalam pembuatan silase komplit cukup tinggi dengan tingkat pemahaman mencapai 82,5\%. Secara fisik, silase yang dibuat memenuhi kriteria silase yang baik yakni bau khas silase (asam), warna hijau kecoklatan dan bertekstur padat, $\mathrm{pH}$ 3,48 dengan tidak adanya jamur, kandungan nutrisi silase yang tergolong tinggi serta palatabilitas ternak terhadap silase yang tergolong tinggi.

\section{UCAPAN TERIMA KASIH}

Ucapan terima kasih diberikan bagi LPPM Universitas Timor sebagai penyandang dana dalam kegiatan pengabdian pada masyarakat sehingga telah berjalan dengan baik, serta masyarakat Desa Kuaken khususnya KWT Mawar yang telah menerima tim sebagai mitra dalam memajukan produksi peternakan.

\section{DAFTAR PUSTAKA}

Church, D.C. \& W. G. Pond. 1988. Basic animal nutrition and feeding. 3nd Ed. John Wiley and Son, New York.

Hermanto. 2011. Sekilas Agribisnis Peternakan Indonesia. Konsep pengembangan peternakan, menuju perbaikan ekonomi rakyat serta meningkatkan gizi generasi mendatang melalui pasokan protein hewani asal peternakan. [diakses tanggal Oktober 2020]

Mayasari, D., E.D. Purbajanti dan Sutarno. 2012. Kualitas hijauan gamal (Gliricidia sepium) yang diberi pupuk organik cair (POC) dengan dosis berbeda. Animal Agriculture Journal, 1 (2) : 293-301.

McDonald P, Edwards RA, Greenhalgh JFD, Morgan CA. 2002. Animal Nutrition. 6th Ed. Harlow (GB): Pearson Education.

Sayuti, M., F. Ilham dan T.A.E. Nugroho. 2019. Pembuatan Silase Berbahan Dasar Biomas Tanaman Jagung. Jurnal Pengabdian dan Pemberdayaan Masyarkat (JPPM), 3 (2) : 299-307. 
Sikone, H dan G.F. Bira. 2016. Pengaruh pemberian tepung biji gamal (Gliricidia sepium) sebagai pengganti bungkil kedelai dalamransum terhadap kadar hemoglobin dan nilai hematokrit anak babi lepas sapih. Journal of Animal Science (JAS), 1 (4) 41-57

Siregar, S.B. 1996. Pengawetan pakan ternak. Penerbit Penebar Swadaya.Jakarta.

Soekanto, L., Subur, P., Soegoro, M. Riastianto, U., Muridan, Soedjadi,Soewondo, R. Toha, M., Soediyo, Purwo, S., Musringan, Sahari, M danAstuti, 1980. Laporan Proyek Konservasi Hijauan Makanan Ternak Jawa Tengah. Direktorat Bina Produksi, Direktorat Jenderal Peternakan, Departemen Pertanian dan Fakultas Peternakan Universitas Gadjah Mada,Yogyakarta

Tahuk, P.K., G. F. Bira and H. Taga. Physical characteristics analysis of complete silage made of sorghum forage, king grass and natural grass. IOP Conf. Series: Earth and Environmental Science 465 (2020) 012022. doi:10.1088/1755-1315/465/1/012022.

Tahuk, P.K dan G.F. Bira. 2019. Peningkatan produktivitas ternak sapi potong melalui penerapan teknologi pengawetan pakan (silase komplit). Bhakti cendana, 2 (1) : 3037.

Wati, W.S., Mashudi dan A. Irsyammawati. 2018. Kualitas silase rumput odot (Pennisetum purpureum cv.Mott) dengan penambahan Lactobacillus plantarum dan molasses pada waktu inkubasi yang berbeda. Jurnal Nutrisi Ternak Tropis, 1 (1) : 45-53. 